\title{
TRANSLATING PERSONALITIES IN PERSUASION (2007) AND MISS AUSTEN REGRETS (2008)
}

\begin{abstract}
Bianca Deon Rossato é professora de Língua Portuguesa e Língua Inglesa no Instituto de Desenvolvimento Educacional do Alto Uruguai - IDEAU, mestre em Letras - Estudos Literários, pela Universidade de Passo Fundo - UPF e doutoranda do Programa de Pós-Graduação em Literatura Estrangeira Moderna, pela UFRGS. Email: bianca_rossato@yahoo.com.br
\end{abstract}

\author{
Resumo: \\ $\mathrm{O}$ artigo investiga as obras fílmicas Persuasion \\ (2007) e Miss Austen Regrets (2008) a fim de \\ compreender, como o processo de tradução se \\ dá, especialmente no que se refere a representar \\ traços de personalidade.
}

\begin{abstract}
:
This paper aims to investigate the filmic works Persuasion (2007) and Miss Austen Regrets (2008) so as to understand how the translation process occurs especially when it comes to represent personality traits.
\end{abstract}

\section{Introduction}

Endeavouring to write about Jane Austen has become a ritual of introduction to pop culture in the last ten years as everything connected to all things Austen expands every day. "There comes a time when one realizes that talking about Jane Austen is like threading in over charted territory - being well aware of the paths that have been taken before, and unsure if there still is any land to be discovered and conquered" (Ramgrab, 2013, p. 10). In any case, each new production either inspired on her work, or on her biography may set out for a new possibility of analyzing the processes of such productions and also their impact in the twenty-first century reader/viewer. So as to do that, this article aims to present a general overview of the processes of adaptation, especially considering the personalities of characters in the film Persuasion, directed by Adrian Shergold, released in 2007, and the film Miss Austen Regrets, directed by Jeremy Lovering, released in 2008, as appropriations of Austen's Persuasion (1818) and her life.

The process of adaptation from literature to cinema is inherent to the birth of cinema since it relied on the knowledge the audience already had of literary works and also their popularity. Thus such source of inspiration has been used over the twentieth century as well as in the beginning of twenty-first century. The connection with literature raised an endless list of topics for discussion among which the most focused on is the aspect of fidelity. The first half of the twentieth century witnessed discussions on the loss of the aura of works of art because of reproduction (Benjamin, 1935), which impacted deeply on the prestige of films once they were never considered as good as their source text - the literary work of art. (Cartmell, 2007). The films were merely considered secondary works never to be taken seriously as autonomous works of art. Such perspective, though, seems to have been undergoing dramatic changes over the last two decades. 
So as to understand the rising of adaptation in the last thirty years it is fundamental to at least glimpse at the cultural context of the period. Peter Brooker (2007, p. 109), when analyzing pastiche, intertextuality and re-functioning, observes that it was the postmodernism in the early 1980s which brought "a new vocabulary and perspective upon relations between the real and the image, and the present and past". As he states, this movement occurred as a response "to the newer reproductive media and information technologies and to trends in film and TV which seemed increasingly to feed off repeats and remakes". Of course, once considering the "repeats and remakes" it is understood that those "tendencies undermined the concept of the original and therefore had clear implications for the study of adaptations". Therefore, studies of adaptation switched focus from "fidelity" to the adaptation as a work of art in itself - as a form of translation ${ }^{\mathrm{i}}$ insofar as it translates the content from one medium - the literary work - into another - the film - observing the latter's specificities. Julio Plaza (2003, p.1) observes that translation "as a creative movement of languages has nothing to do with fidelity, for it creates its own truth and a strong relation woven among its various moments, that is, between past-present-future, place-time where the transformations occur, ii . Linda Hutcheon (2013, p. 4-6) argues that an adaptation must be observed in three specific ways: as a formal entity or product, a process of creation and a process of reception. She affirms that

seen as a formal entity or product, an adaptation is an announced and extensive transposition of a particular work or works. This "transcoding" can involve a shift of medium (a poem to a film) or genre (an epic to a novel), or a change of frame and therefore context: telling the same story from a different point of view, for instance, can create a manifestly different interpretation. Transposition can also mean a shift on ontology from the real to the fictional, from a historical account or biography to a fictional narrative or drama. (Hutcheon, 2013, p.7-8)

Such a perspective encompasses the concept of translation from literature to cinema, which is the focus of the analysis thus conducted. However, it determines the final product of a process to which attention must be paid, that is, the process of creation which "always involves both interpretation and then (re-)creation". Especially considering that an adaptation involves a shift in medium, one cannot suppose that the ways a literary work has its narrative organized will be the same ones as a film's. At the same time, each work of art is a product of a subjectivity in a specific context. Hence, any approach to it will involve interpretation and re-creation in its process of adaptation. Finally, Hutcheon $(2013$, p.8) states that an adaptation should also be seen as a process of reception in which it is "a form of intertextuality: we experience adaptations (as adaptations) as palimpsests through our memory of other works that resonate through repetition or variation". It is a matter of dialoguing with its predecessors and, understood like that, no strict fidelity should be observed. 
It is precisely the "repetition or variation" according to Hutcheon which seems to attract the audience's attention: "part of this pleasure, I want to argue, comes simply from repetition with variation, from the comfort of ritual combined with the piquancy of surprise. Recognition and remembrance are part of the pleasure (and risk) of experiencing an adaptation; so too is change". Hutcheon strongly opposes the concept of fidelity, as a literary text and a film are products of completely different media and should be seen as such. She observes that although an adaptation comes from a source text - usually a literary one -, it should be seen as "an autonomous work that can be interpreted and valued as such". Therefore, "an adaptation has its own aura, its own 'presence in time and space, its unique existence at the place where it happens to be' and, thus, "adaptations are never simply reproductions that lose the Benjaminean aura". (Hutcheon, 2013, p 4-6).

Robert Stam (2005) appropriates the concepts of dialogism and intertextuality as proposed by Mikhail Bakhtin so as to move beyond the ambivalence of having to choose one or the other to a more open appreciation of art. Brooker (2007, p. 112) quotes Stam: "The concepts of dialogics and intertextuality [...] can help us move beyond the stark 'either... or' to a thoroughly open appreciation of art as, in Stam's words, the "endless permutation of textual traces"'. That way, as Stam argues, "the idea of "intertextual dialogism" undermines the hierarchies and prejudice governing the common response to adaptations and, as he puts it, helps "us transcend the aporias of "fidelity". Also, the concept of translation suffered changes from its original idea, that is, the fact that "the concept and practice of translation have a history in which privilege and dominance is conferred upon one language and culture over another". Inversely, as Brooker explains

neither the "original" text and culture, nor its translation and corresponding culture can be deemed homogeneous entities. Rather, the practice of translation, contends Naoki Sakai, is "radically heterogeneous". Sakai adds that "the translator is also an interpreter" and in an "extremely ambiguous and unstable" relation to both the original author (addresser) and the reader (addressee). Such thinking undermines any essentialized notion of either prior or subsequent texts and participants and the traditional assumption that a level of underlying sameness exists between them. Rather, translation becomes a "hybridizing instance" marked by disparity, gaps, and indeterminacy rather than equivalence. (Brooker, 2007, p. 113)

Appropriating such a concept of translation to the studies of adaptation leads the theorist to observe that this "occurs across media and genres" and there is no need on the part of the viewer to know or recognize the source text. Hence, "an adaptation will stand in a set of potential intertextual or dialogic relations" and because it is an autonomous work of art, they need not be actualized at any time "in order to afford 
pleasure and understanding". One need not know that Bridget Jones's Diary (2001) has elements of, or converses with Jane Austen's Pride and Prejudice (and also the BBC 1995 Pride and Prejudice) in order to understand its plot, flow and particularities. Of course, the ones acquainted with such connections will observe more specific details and might have a deeper understanding of some nuances. Such is the new movement established by adaptations, an inversion of a chronological order of things, as viewers or readers may go from adaptation to source text resituating and transforming the "supposedly fixed and authentic original". (Brooker, 2007, p.114)

\section{1) Persuasion the film and Persuasion the novel}

Persuasion, along with Northanger Abbey, was the last of Jane Austen's work which was published posthumously and it represents her mature years. Austenian works are still commonly seen as love stories and happy endings only, which contributes to the designation of chick lit it receives. Nevertheless, once one surpasses the first superficial level of reading, they come across an ironic and bold narrator, alert to the flaws of others, especially those of the aristocratic class, and that reveals other themes such as the differences between social classes and genre conflicts. Present in all her work, they seem to be highlighted in the plot and characters of Persuasion, whose protagonist, Anne Elliot, shows a feebleness of character and lets herself be persuaded by a family friend - Lady Russell - not to accept Frederick Wentworth as her spouse, for it is considered an unsuitable match. Reading the book, the reader is acquainted with such events through Anne's memories, which have come back to haunt her once she learns that Wentworth, now Captain, owner of a considerable fortune earned in the British navy, has returned.

On the way to the "happily ever after", with the longed reconciliation of Anne Elliot and Captain Wentworth, the reader faces him/herself with a sharp tongue analyzing the behavior of all, but especially of Sir Walter Elliot, Anne's father, Ms. Elizabeth Elliot, her older sister and Ms. Clay, the latter's companion. Either through the narrator's voice or through his, Sir Walter Elliot reveals his superficiality and vanity: "Vanity was the beginning and the end of Sir Walter Elliot's character; vanity of person and of situation". He has such a high consideration of himself that one reads the narrator's words thinking they're Sir Elliot's and that he is observing someone other than him: "He considered the blessing of beauty as inferior only to the blessing of a baronetcy; and Sir Walter Elliot, who united these gifts, was the constant object of his warmest respect and devotion",iii. (1.6)

Unlike a literary piece, the film's greatest power lies in the images. In the ITV's 2007 Persuasion, it is precisely through the images that Sir Walter Elliot's vanity has its pick as he enters the Pump Rooms where a concert is to happen and to which their high- 
esteemed cousin Lady Darymple is honored. The image of a man trying to check his hair on the back of a spoon enhances the caricature created of him, as well as the many times the viewer sees him looking in the mirror. Also, the image in the film of a room in Kellynch Hall full of mirrors and Admiral and Mrs. Croft's surprise as they enter it reinforce Austen's satire of the aristocracy.

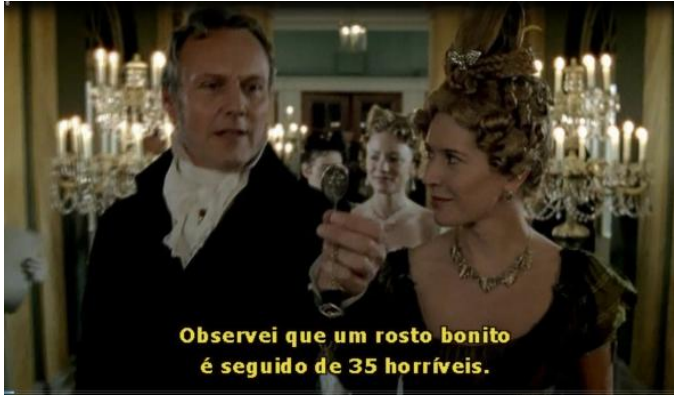

Persuasão (2007) - Cena 8

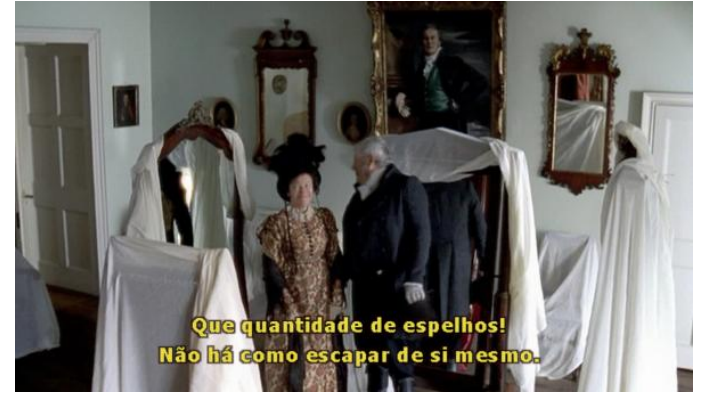

Persuasão (2007) - Cena 4

The shift of medium from written text to film operates a significant modification in the narrator's perspective. In the book, it is through the narrator's voice that the reader is acquainted with most of the character's personality traits and thoughts. Having all of that through voice-over in a film has already been proved unsuccessful in most cases. The shift then occurs from third to first person as in the case of Sir Elliot's thoughts, which show that he is indignant at the number of ugly women in Bath, and thus enhance the expression of his superficiality. Bellow is the example:

Source Text

Sir Walter thought much of Mrs Wallis; she was said to be an excessively pretty woman, beautiful. "He longed to see her. He hoped she might make some amends for the many very plain faces he was continually passing in the streets. The worst of Bath was the number of its plain women. He did not mean to say that there were no pretty women, but the number of the plain was out of all proportion. He had frequently observed, as he walked, that one handsome face would be followed by thirty, or five-and-thirty frights" (15.12)

\section{Adaptation}

Sir Walter: I must say, though, the worst of Bath is the number of plain women. I frequently observe that one pretty face would be followed by five and thirty frights. And as for the men ...

Although such opinion seems to be disguised through the narrator's voice in the original - which grants Austen's subtlety -, viewing Sir Walter Elliot himself saying 
such words in the adaptation intensifies his representation of vanity and futility, reinforcing his ridicule. The same happens to his daughter Ms. Elizabeth Elliot, who shows more attention to Ms. Clay than to her own sister, Anne. Again the third person ideas are brought into the character's own speech.

Source Text

She could imagine Mrs. Clay to have said, that "now Miss Anne was come, she could not suppose herself at all wanted;" for Elizabeth was replying in a sort of whisper, "That must not be any reason, indeed. I assure you I feel it none. She is nothing to me, compared with you;" (16.1)

Another change which emphasizes the sagacity and irony in the original is the fact that Anne, when arguing with her father over why she had changed a visit to lady Darymple for the company of an old school friend, Mrs. Smith, verbally expresses an idea which she keeps to herself in the original: "Perhaps she is not the only poor widow in Bath with little to live on and no surname of dignity." In the original, she keeps it to herself in respect to her father, considering that he might see that for himself.

Anne could have said much, and did long to say a little in defense of her friend's not very dissimilar claims to theirs, but her sense of personal respect to her father prevented her. She made no reply. She left it to himself to recollect, that Mrs. Smith was not the only widow in Bath between thirty and forty, with little to live on, and no surname of dignity. (17.16)

The movie scene, where father and daughter exchange looks, makes it even clearer that the reference is to Mrs. Clay, who was also a "widower between thirty and forty, with little to live on, and no surname of dignity". Through the image one may be able to explicit what seems to be in a potential state in the source text, something that one desired to say but, due to social constraints, could not. In that aspect it might be argued a sense of proximation in this scene, as it portrays Anne explicating her opinion, something a twenty-first century young woman would not refrain from doing.

Although mostly demystified, the concept of "fidelity" still penetrates not only some theorists' ideas but also fans'. The latter (women in general) still mistrust the changes and variations a director makes while appropriating texts such as Persuasion, especially if it is proposed as a heritage film, even though they are readily consuming everything connected to Austen and thus fomenting the market of derivative works. Nevertheless, Hutcheon (2013, p. 16) informs that "transposition to another medium, or even moving within the same one, always means change or, in the language of new 
media "reformatting"". That means they are "re-mediations, that is, specifically translations in the form of intersemiotic transpositions from one sign system (for example, words) to another (for example, images)". She understands it as "translation but in a very specific sense: as transmutation or transcoding, that is, as necessarily a recoding into a new set of conventions as well as signs".

When it comes to the translation of the main characters, Anne Elliot and Captain Wentworth, Sally Hawking and Rupert Penry-Jones's performance is decisive so as to realize the representation of the protagonists of the source text. Short, pale and slim, with a resigned look, the actress is successful when representing the twenty-seven year old young woman, visibly saddened, but conscious of how mistakenly she had acted almost eight years before - when she refused Wentworth's proposal -, and how she must follow her own mind now. The scene described above, with her confronting her father is an example of how she may not allow to be persuaded anymore, just as when she convinced her sister Mary and her husband Charles Musgrove that she was not hungry and thus could perfectly stay and take care of little Charles who had fallen down a tree earlier, instead of dining with the Crofts at Kellynch Hall. The choice of so clearly portraying both scenes reinforces the protagonist's growing, as well as the exchanged looks between Anne and Wentworth when they inevitably see each other help build on the suffering of both, the former regretting, the latter hurt.

Along with the previous scenes, the one which portrays Louisa Musgrove's fall at the Cobb in Lyme, provides the spectator the possibility of seeing a determined woman in Anne Elliot, as it is she who readily deals with such a serious situation. It also shows Captain Wentworth acknowledging it and realizing he might still love her. Below there are two cuts from the film in an attempt to better explicit what has just been said. Also it provides a moment for discussion on the difficulties of trying to tackle a language with another, since it may be difficult at times to say in words what the images represent.
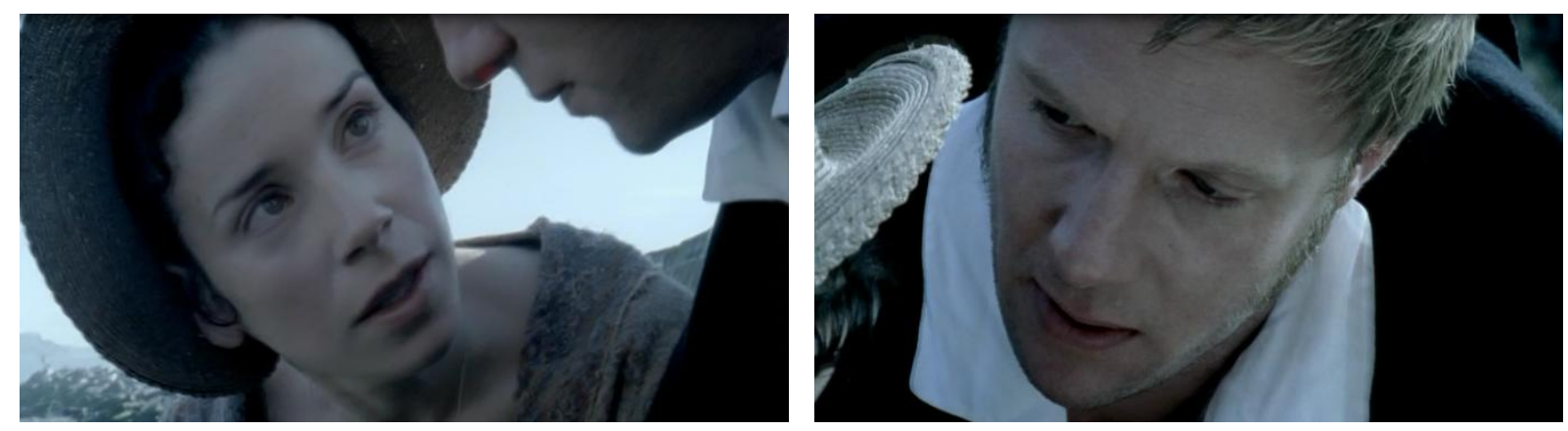

Persuasão - Cena 1

Dealing with the representation of Anne Elliot once again brings to light the issue of fidelity to the source text and the valuing of the second degree text - the film - 
as a work of art which should be seen as autonomous and capable of being understood in its own. That is reflected when Anne finds herself alone writing in her diary, moments in which the spectator sees himself or herserlf accessing her thoughts. In such occasions she looks at the camera, and aesthetically speaking, that brings the audience to the illusion that she looks at them, bringing them closer to her, sharing her suffering and angst. Some might argue such a resource is overly used by the director; however, it imprints his own style and contributes to the work's autonomy. In order to demonstrate it, two scenes- one from the beginning and another from the pick of her suffering exemplify the device.

The first close-up on her face happens as she wonders if Wentworth is already

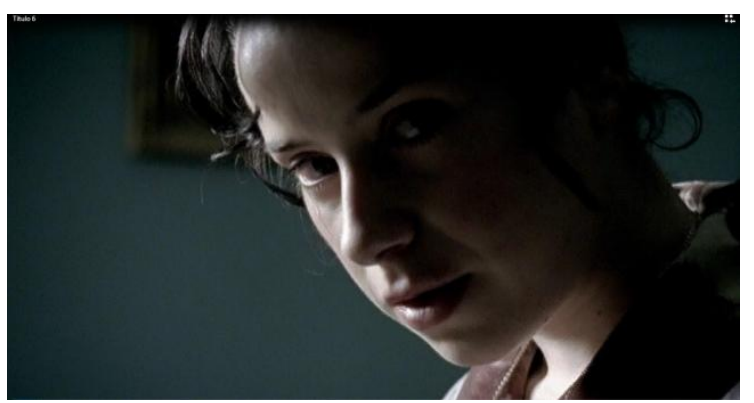
married and acknowledges his eligibility

and her lost chance.

Is he married? I do not know that he is, and yet, so eligible a gentleman would surely by now have formed an attachment. Will he bring his wife here? And his children? I only pray that I am spared any meeting. I know my chance of happiness has passed forever, but to be reminded of it by his presence here would, I'm certain, be more than my spirits could bear.

The second scene shows her crying, face full of tears as she reads a letter she received from her brother-in-law informing her of Louisa Musgrove's probable engagement. Not fully aware of the changes which have already occurred and the fact that Louisa is to marry Captain Benwick, she is sure the young girl will marry Wentworth and she understands her love is lost. Her gazes at the camera/spectator allow a speculation over the director's decision to insert such a technique in the plot. They may resemble a talk she would have with whoever is looking at her, apparently the one allowed to know her deeper feelings. Therefore the viewer seems to be spoken to: "You, dear spectator, who have already read my story from Austen's pen, you know how I feel". Clearly the director uses that as his signature and it ends up resulting in a more direct sort of dialogue with Austen's work.

In terms of ambience, the location for Kellynch Hall and Uppercross as well as the takes on cloudy and rainy days in Lyme and Bath certainly contributed to Anne's atmosphere of melancholy, just as her dresses in dark pale colors corroborate the source text. It is only by the end, when Wentworth shows her the house as a gift that she wears 
a lighter-colored dress. Such re-mediations are necessary when a literary text is translated to a medium such as a film. However, not all that was translated seems to have a purpose in itself, that is, a feasible explanation in the film. Again it should be stated that it is not a matter of fidelity to the original's plot, but coherence in the film. The scene with the gift just mentioned culminates a series of alterations which diminish its value as a heritage film.

It is questionable, though, if such alterations were director and scriptwriter choices or if the translation from one medium into another does not accommodate all of the possibilities of representation. In any case it is worth analyzing some of them. In Persuasion, the source text, one very important scene is the first encounter between Anne and Sir Elliot at the Cobb in Lyme. Her countenance clearly calls his attention to which she blushes and Wentworth, as a witness to it, feels discomfort as if his passion raised again. In the film not even their faces are clearly seen because of the mist and fog in the area and the scene goes on so fast one hardly notices the man is Sir Elliot. Also, the unfolding of the film, when Anne and Wentworth finally make amends, brings great discomfort to the viewer acquainted with the original. In the source text the tension and suspense is built through a conversation Anne has with Captain Harville about men and women's consistency in love to which Wentworth overhears. The reader only knows his reaction to the conversation as Anne reads his letter.

In the film, however, the scene with the conversation is suppressed and the content of the letter thus altered and, in an attempt of representing the tension, the director has Anne running around Bath in a sort of chase for Wentworth. Her angst is intensified by the obstacles she finds along the way, the most important being Mrs. Smith's revelation of Sir Elliot's real character. It seems hard to picture a heroine such as Anne Elliot running breathless, almost sweating around Bath, as she does not break any social conventions of female behavior, not even after she is seen as a determined young woman. One would expect Elizabeth Bennet's long walk in the countryside, fifteen inches deep in mud as she is naturally a determined young lady.

Finally, it is relevant to mention that either being direction choices or translation limitations, the work as a unit brings an important discussion not only on translation but also on the understanding of Austen's works, something unobserved by the first theorists who explored her work. Claire Harman (2009) notices that "in 1890 her first professional academic biographer, the historian Goldwin Smith, had shone some light of his scholarly mind on his subject only to report that there was nothing in Austen to illuminate". Smith says that "there is no hidden meaning in her; no philosophy beneath the surface for profound scrutiny to bring to light; nothing calling in any way for elaborate interpretation". Well, some handfuls of analysis about the austenian work have proved him wrong, positioning her alongside Shakespeare: "the true connection between Austen and Shakespeare lay in their popularity, accessibility and impact on readers' affections. Harman (2009) also observes that "both Shakespeare and Jane 
Austen had managed to find popular audience long after their own time, and to appeal to them over the heads of an interpretive elite. Thus, the approximation between Austen and her public - through translations and derivative works - allows the exploration of even subtler aspects of her novels and contributes to maintain her statues as a canon, although some fear still remains as to what is understood as Jane Austen's work after the adaptations.

\section{2) Miss Austen Regrets (2008): creating a myth}

Miss Austen Regrets is a filmic production from 2008 which for some seems like a response to Becoming Jane (2007). Both are biopics, the former endeavors in Austen's late years while the latter in her teenage years. Miss Austen Regrets, commissioned by BBC, was directed by Jeremy Lovering with script by Gwyneth Hughes. According to Ramgrab (2013, p, 13), a biopic is a work of fiction whose aim is "to appropriate elements and events of a historical person and try to recreate those events in a filmic narrative that can be understood by both the audience that is familiar with the life of the author and that which is not". Accordingly, Ramgrab (2013, p. 92) highlights that "the biopic is not different than a regular filmic adaptation of novels, and therefore cannot be judged by the aspects that it gets wrong, or changes or omits - fidelity is not the objective of the biopic, otherwise it would be a documentary." Thus, one can understand that "the life of the author may be the primary source-text, but it is by no means the only one: the author's body of work, as well as criticism [on her work] can also be used to achieve the adapter's intended result". Once being "an attempt at reconstructing historical events while at the same time undercutting the idea of one single historical referent, subverting it by pointing to several referents that come from historical narratives as well as fictional narratives", the biopic may be considered a product of historiographic metafiction. It is then a translation of the life of the author permeated by the creation of the director and scriptwriter.

When it comes to investigate Jane Austen biography it is a well-known fact that the information available is scarce. Jane Fergus (2005, p.3) states that "biographical information on Austen is famously scarce". She adds that "most people who read the novels know that she was a clergyman's daughter who grew up in a country parsonage with several brothers and one beloved sister, that she never married and that she died relatively young". Part of that is owed to the fact that there are no diaries left and that part of her correspondence was destroyed by her sister Cassandra, her depositary. Austen's great-nephew, Fanny Knight's son, Lord Brabourne (2009, p. 29), reports that "in all probability [...] when Jane Austen died in 1817, and all her papers and letters came into her sister's possession, the latter did not think her own letters worth preserving, and they were accordingly destroyed". Thus, "despite the effort of several 
accomplished biographers to dispel some early misconceptions about the author's life, the case with Jane Austen is one of those instances where the boundaries between history and fiction become blurry." (Ramgrab, 2013, p. 12).

It may be exactly the existence of such gaps about the writer's life, as Fergus posits, that allows both fans and scholars to speculate on her life and create "as many Janes" as it is possible, to the point of creating a Jane Austen vampire. Linda Hutcheon (1988, p. 118) conceptualizes historiograpic metafiction and observes that "postmodern intertextuality is a formal manifestation of both a desire to close the gap between the past and present of the reader and a desire to rewrite the past in a new context". Such a conception brings to light the comprehension of why there have been so many new productions both on her works and her life. Ramgrab (2013, p. 13-14) observes that

while in historical fiction real life characters and events are used as a way to legitimize the narrative, the author of historiographic metafiction appropriates these elements and assimilates them into the story, but with no commitment to truth, or historical accuracy. In fact the author may choose to sever any or all bonds with historiography, questioning the boundaries between fact and fiction, while the resulting text urges the reader to question the notion of truth that arises when talking about History. (Ramgrab, 2013, p. 13-14)

Claire Harman (2009) investigates the reasons why Jane Auten "has conquered the world", and observes that "a strong myth or 'product legend' like hers depends upon separation from its origins". She mentions Charnes in order to explain that the myth "requires 'the naturalizing or forgetting of its own history' (a process which began for Austen even before her history was written). Accordingly, "an opinion formed by a small group can in this way spread out and be held by a much larger group; its 'halfreal, half-ficticious' quality becomes not just the way it disseminates effectively, but the reason it does". Two important facts are then understood for the analysis below: 1) Jane Austen the myth is considerably distant from her origins; 2) a whole lore surrounds her life and reinforces the permanence of the myth.

Concerning Miss Austen Regrets, Hughes - the scriptwriter - explains that "the script is very tightly based on Austen's surviving letters to her sister and to her young niece, Fanny. So I must share the credit for quite a lot of the dialogue with Miss Austen herself!". Such a fact introduces some important aspects to the analysis, especially as it offers the possibility of seeing the film as a translation into images of the writer's life. Also, it offers a counter argument to the biography written by Austen's brother, Henry Austen - A biographical notice of an author - a version of her life which strongly disappoints Austen's fans as it portraits a person incapable of reaching the level of irony read in her works.

Olivia Williams was the actress selected to play Austen's role in a movie which starts with the writer in her twenties receiving Harri Bigg-Wither's proposal which she 
hastily accepts in one night and refuses the next morning, maybe persuaded by her sister Cassandra, played by Greta Scacchi: "Jane... Are you sure?" These very first moments immediately point to Persuasion and Anne's refusal to Wentworth's proposal:

Such opposition, as these feelings produced, was more than Anne could combat. Young and gentle as she was, it might yet have been possible to withstand her father's ill-will, though unsoftened by one kind word or look on the part of her sister; but Lady Russell, whom she had always loved and relied on, could not, with such steadiness of opinion, and such tenderness of manner, be continually advising her in vain. She was persuaded to believe the engagement a wrong thing: indiscreet, improper, hardly capable of success, and not deserving it. (4.4)

In the biopic, the next morning brought not only the rain gently touching the carriage window, but also Jane's refusal and the uncertainty that she had made the right decision: "Tell me I have done the right thing. Tell me I was right to change my mind. Dear God, let me never regret this day." According to Ramgrab (2013, p. 6), this thought known through voice-over in "echo of Anne's internal conflict when she learns of Wentworth's return": "More than seven years were gone since this little history of sorrowful interest had reached its close [...] She had been forced into prudence in her youth, she learned romance as she grew older: the natural sequel of an unnatural beginning" (4.7-9). As in Persuasion, several years have passed until the viewer sees a mature Jane Austen, apparently more confident and summoned to help her niece, Fanny Knight, to choose a husband.

It is here then, in the dialogue between Jane and Fanny, Jane and Cassandra and some family members that the viewer realizes a different woman from that portrayed by James Austen-Leigh in his Memoir: "A life of usefulness, literature, and religion, was not by any means a life of event" (Austen-Leigh, 2002, p. 137). Lord Brabourne, being further in time than Austen-Leigh, presents the five letters left from his mother, Fanny and Jane. Though not transcribed with academic accuracy, the Brabourne letters, published in 1884, present as he comments a "vividly characteristic of the writer", "besides they differ from all the preceding letters in that they are written, not to an elder sister, but to a niece who constantly sought her advice and sympathy, and whom she addressed, of course, in a different manner, and from a different standpoint" (Brabourne, 1884) .

The film translates a Jane Austen living a lot closer to the people around and even to her possible suitors than her readers would imagine through her first biographies. Undeniably, the reasons as to why she did not marry are fertile terrain for speculation. In the film she is portrayed rather comfortable to flirt - or at least to verbally provoke - the men around her. The first example is reverend Mr. Pampillon, and as she prepares to tease him she talks to Fanny: 
Jane: I just don't think you've got any chance of beating me to the altar. I'm expecting a proposal at any moment.

Fanny: That's such a silly old joke.

Jane: Learn from me, Fanny. All any gentleman needs is an opportunity.

Just after, she moves closer to the reverend and as she compliments him on the sermon, she teases him:

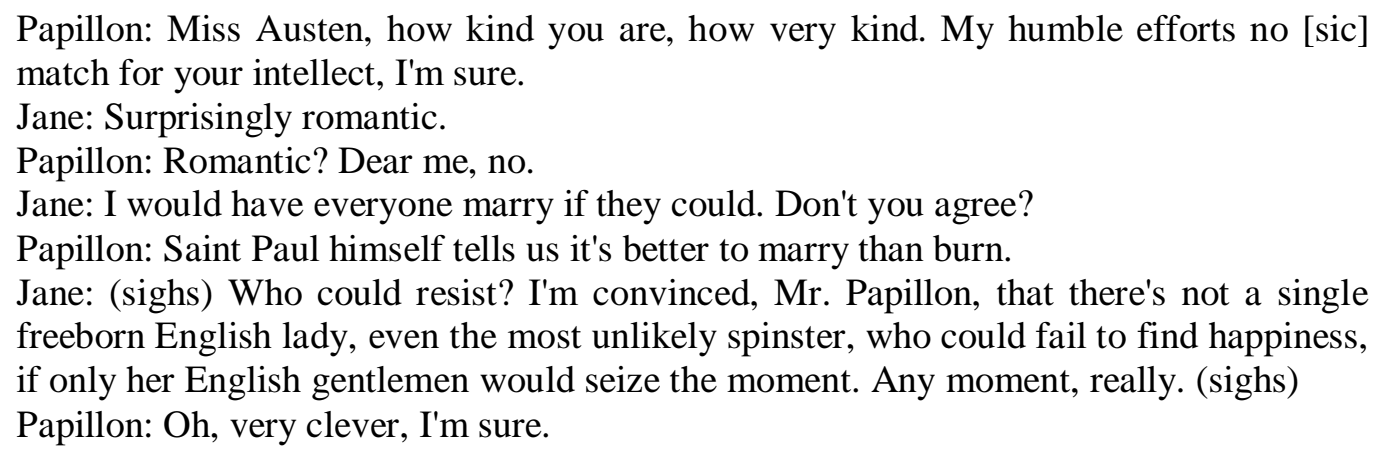

The exchange of looks between them, and Cassandra's remark (-You shouldn't torment the poor fellow. Like a cat with a mouse. And it's cruel!') as she sees Jane, reveals an extrovert protagonist willing to find fun in everybody around her. So, when Fanny cries for possibly having lost her chance of Mr. Plumptree proposing to her, Jane promptly offers her "widower with six children". Quite differently from Henry Austen's portrait of her: "If there be an opinion current in the world, that perfect placidity of temper is not reconcilable to the most lively imagination, and the keenest relish for wit, such an opinion will be rejected for ever by those who have had the happiness of knowing the authoress of the following works". Well, if it is possible that such a playful, sharp tongue person is also serene, there is no way to prove. Katherine Sutherland (2009, p. 13) wonders "how is it possible to recognize in their carefully fashioned portrait of a conformable family member the writer of such startlingly original novels: novels, moreover, that point up the difficulties and constrictions of family identity?" The researcher reinforces that one does not aim to read the writer's life in her novels, something too naïve. However, there seems that "the fiction must have a plausible psychogenesis. It does not; and not only does it fail in this respect, it is disconcerting to discover how little in the early family accounts sought to make the connection".

In any case, Miss Austen Regrets seems to try to fill such gap, as a response to Henry Austen, contributing to the construction of a postmodern icon of Jane Austen: a bold writer who knew just how to use irony underneath a romantic layer. Once more, Persuasion contributes to this aspect. In the following excerpt the narrator refers to one dead son of the Musgroves. 
The real circumstances of this pathetic piece of family history were, that the Musgroves had had the ill fortune of a very troublesome, hopeless son; and the good fortune to lose him before he reached his twentieth year; that he had been sent to sea because he was stupid and unmanageable on shore; that he had been very little cared for at any time by his family, though quite as much as he deserved; seldom heard of, and scarcely at all regretted, when the intelligence of his death abroad had worked its way to Uppercross, two years before. (6.23)

It seems unlikely that a person possessing such a mild temperament as Henry Austen shows would be able of such acid words. And it must be reinforced those are words from her writing, and not any postmodern adaptation. Also, in an attempt to portray a "real" Austen, and not a family fabricated one, the director and scriptwriter favor on another of the doubts concerning her life: love. Did she ever fall in love? Who with? What happened? are just some of the questions her fans ask. So as to represent that, the director and scriptwriter bring to the scene the figure of Brook Edward Bridges and portray him as the suitor who Jane seemed to have liked the most. He is first seen approaching her brother's house which leaves her in a state of affliction. Not knowing how to behave exactly, she hides next to the little table at which she was writing. What seems to be reminiscent of the past becomes the focus of the plot.

In real life Brook Edward Bridges was Edward Austen's brother-in-law. Jane's letters to her sister reveal Bridge's sympathy towards Jane: "It is impossible to do justice to the hospitality of his attentions towards me; he made a point of ordering toasted cheese for supper entirely on my account" (27 August 1805). Deydre Le Faye observes that "it seems possible that Edward Bridges proposed or attempted to propose to [Austen during her visit in 1808], proposal which she had no difficulty in politely rejecting". Some time later, Jane learns through her sister that Bridges got engaged to Harriet Foote, a fact which makes Jane concerned: "Your news of Edw: Bridges was quite news... I wish him happy with all my heart, $\&$ hope his choice may turn out according to his own expectations, \& beyond those of his Family".

In the film, Jane Austen and Brook Bridges have pieces of conversation mingled with other family events. When they are alone, their conversation focuses basically on the past, a past they apparently had together, since we learn from them that he seemed rather in love with her and even proposed, to which she answered negatively. Although not indifferent to his feelings, she seems to be quite sure of her decision of not marrying as their final dialogue in the motion picture demonstrates:

Bridges: I suppose no man of flesh and blood would ever be worthy of the creator of Mr. Darcy.

Jane: You're all quite wrong about him. He wouldn't have done for me at all.

Bridges: If I had plucked up the courage after we danced at the ball...?

Jane: We would've been too young.

Bridges: And later, when I did ask you...? 
Jane: I simply went off the whole idea of marrying anybody.

Bridges: Tell me now you regret it. Tell me now that sometimes in the night you think of me. Tell me even if it isn't true.

Jane: What on earth would be the point?

The creation of such events seems to fulfill her readers' expectations of having their beloved writer living love stories and yet, as she seems determined upon not marrying, the film maintains itself close to what is known of her life: that actually she did not marry. Historical events are mingled with fictional ones in an attempt to create the "ideal" Jane Austen. Finally, referring to Tom Lefroy, the most well-known of her suitors, Jane briefly tells Fanny about the events and once more comes the reference to listening to "wiser minds" and ending up not marrying:

Fanny: What happened?

Jane: Wiser heads than mine noticed that we neither of us had any money. So at the end of the summer he went home. Fortunate fellow, married an heiress.

Fanny: Was he the one?

Jane: No, he wasn't. And I'm telling you this because it hurt me for about five minutes and then it passed. You're so young. Depend upon it, Fanny, the right man will come along.

As she tells Fanny the story, and tries not to feel sorry about it, Olivia Williams's performance makes the viewer believe deep inside she is sorry for not having married him. And not marrying at her time was a problem to any woman, once it affects not only her respectability but also her family's along with her future. When arguing with Edward Austen about her work, she listens to him say "Dear Lord, I do wish you wouldn't think of it as writing for money", to what she replies "Sense and Sensibility has brought me a hundred and forty pounds. May I not be proud of that?" This sense of independence is reinforced as she wonders around London in search of a doctor for her brother Henry:

Jane: Excuse me. I'm looking for a doctor.

Nurse: Come with me.

Jane: Are you the doctor?

Doctor: I'm one doctor among many.

Jane: I need your help. My brother's terribly ill. He's screaming with pain, stomach pain of some sort. It's been going on for ages. He hasn't said a thing. We don't live far away, Hand's Place. I walked here myself.

Doctor: Alone?

Jane: I had no choice.

The film portrays the Jane Austen her fans would like to have known existed: a woman unafraid of surpassing social constraints to do what is necessary or what she 
wants and her writing is an example of that. There is, though, an apparent exaggeration in such independence when she wanders around a house with her niece Fanny Knight, drinking wine and laughing. What seemed plausible to have happened, suddenly makes even her fans a little intrigued with such a scene. When discussed among the family, her works are never seen as mere "happily ever after" love stories, except by Fanny who is still a young girl. One more time, it translates the twentieth century fans/viewers desires of how Austen's work should be seen.

\author{
Hayden: That destiny always provides us with a perfect mate? \\ Jane: I do... when I'm writing a novel. \\ (all chuckle) \\ Fanny: So unromantic. \\ Hayden: Oh, but your aunt's heroines always get it right. Each one marries a wealthy \\ man, each one marries him of love. \\ Henry's governess: And you, Monsieur Haden, what is your idea of the perfect wife? \\ Hayden: A strong mind, a sweetness of manner.
}

The film moves on with the predictable endings: Jane's life fading with a disease unknown at the time and Fanny marrying the "widower with six children" just as her aunt played for long time. Theoretically speaking, it is relevant to mention that the film as a biopic portrays a re-creation of what could have been Jane Austen's life. It translates fans' expectations of what it could have been and frames it, even if only in parts, with some events from Persuasion. Linda Hutcheon discusses Walter Benjamin's argument in "The task of the Translator", observing that "translation is not a rendering of some fixed noncontextual meaning to be copied or paraphrased or reproduced; rather it is an engagement with the original text that makes us see that text in different ways" (Benjamin, 1992, p. 77). She mentions that "recent translation theory argues that translation involves a transaction between texts and between languages and is thus "an act of both inter-cultural and inter-temporal communication (Bassnett, 2002, p. 9).

As a meticulous viewer might have noticed, Miss Austen Regrets not only borrows from the source text Persuasion, but it also borrows from the 2007 ITV's Persuasion film as it portrays Jane Austen's many moments alone writing and coincidently writing Persuasion. It might be seen as the director attempting to show his own reading of both the book and Jane's life, as she too felt a little melancholic about her past, just like her heroin, Anne Elliot. That is not to say Jane used the book as canvas for her life, on the contrary, to use T.S. Eliot's (1922) words, a "poet has, not a 'personality' to express, but a particular medium, which is only a medium and not a personality, in which impressions and experiences combine in peculiar and unexpected ways". For him, "impressions and experiences which are important for the man may take no place in the poetry, and those which become important in the poetry may play quite a negligible part in the man, the personality". 


\section{Final word}

Brian McFarlane (2007, p. 15) states that "every reading of a literary text is a highly individual act of cognition and interpretation". He also says that "every such response involves a kind of personal adaptation onto the screen of one's imaginative faculty as one reads". So he asks "how is any film version, drawing on the contributions of numerous collaborators, ever going to produce the same responses except by the merest chance?" Furthermore, Hutcheon (2013, p. 24) explains that "each mode, like each medium, has its own specificity, if not its own essence". So "in other words, no one mode is inherently good at doing one thing and not another; but each has at its disposal different means of expression - media and genres - and so can aim at and achieve certain things better than others". It is thus not a matter of being faithful, but of understanding the process and the purpose of the adaptation so that success can be evaluated.

Both films - Persuasion and Miss Austen Regrets - are products of postmodern practices widely spread through advances in technology, a cultural environment in which there is no more space for one correct, or better way of rendering a narrative. That brings a complex realm of uncertainties as one is not sure anymore of how to value or consider a work; even the use of the expression "work of art" is of uncertain appropriateness. Nevertheless this is a movement that must be observed and scrutinized; as the more one knows about it the better one can theorize about it. Linda Hutcheon (2013, p. 34) mentions Naramore (2000, p. 6): "it seems that no art can acquire cultural capital until it has theorized itself as medium-specific with its own formal and signifying possibilities". Therefore there is a need of institutionalizing the study of adaptation, not only on Jane Austen and Shakespeare, which are already established as part of the English curriculum, but also adaptation from other authors and other media, such as videogames and transmedia storytelling. According to Linda Troost (in Cartmell, 2007), "adaptations can increase the cultural capital of a literary text".

Jane Austen's case, at least in the last twenty years, seems like an endless circle where increased production leads to increased consumption, and again to increased production. The consequent spread of her work may enable its ressignification as Jorge Luis Borges (1952) realizes in the text "Kafka and his precursors". He posits that some of the concepts or ideas one reads in Kafka's predecessors are only understood, or even seen because Kafka tackled them and because of that, one never reads those poems the same way. Accordingly, T.S. Eliot's (1992) text on "Tradition and the Individual Talent" explicits that "no poet, no artist of any art, has his complete meaning alone". He enforces saying that a poet's significance and appreciation "is the appreciation of his relation to the dead poets and artists. You cannot value him alone; you must set him, for 
contrast and comparison, among the dead". For him that should be a "principle of aesthetic, not merely historical criticism". All these classic references pave the way for new researchers to understand, firstly, that there is no way of saying one has not been influenced in his/her writing. And secondly that there is, therefore, no isolated work and thus it should be evaluated analyzing its context and its relations to other works and its time. Finally, that is how a translation of the literary text Persuasion and Jane Austen's life should be seen, feeding from history and at the same time lending history opportunities of re-reading past events and canonical works of art. That should be the purpose of literary translation, not a mere "an eye for an eye" comparison, as Debora Cartmell (2007, p. 3) mentions.

\footnotetext{
${ }^{\mathrm{i}}$ Other terms could be used, e.g. transmutation, intersemiotic translation, transposition, savaging, among others. For the sake of this analysis the terms used will be translation as the process; adaptation as the product and hipertextuality as the relation between source text and second degree text.

${ }_{\text {ii }}$ My translation.

iii As there are many different publications of Austen's work, the method of citation to them uses the number of the chapter and the number of the paragraph.
}

\section{References}

AUSTEN, Jane. Persuasion. 1818.

Letters of Jane Austen. Volume 1. Edited by Edward Hugessen, Knatchbull-Hugessen, Lord Brabourne, 2009.

AUSTEN-LEIGH, J.Edward. A Memoir of Jane Austen and Other Family Recollections. Edited with an Introduction and Notes by Kathryn Sutherland. Cambridge: 2002.

BENJAMIN, Walter. "The Work of Art in the Age of Mechanical Reproduction". In: Selected Writings, Volume 4: 1938-1940. Cambridge, Mass.: Harvard University Press, 2003, p. 251-283.

. "The Task of the Translator". Translated by Steve Randall. In: TTR: traduction, terminologie, redaction. vol. $10, \mathrm{n}^{\circ} 2,1997$, p. 151-165.

BORGES. J. Luis. "Kafka and His Precursors". Version in Portuguese by Editora Globo. In : Jorge Luis Broges: obras completas. Volume II. 1952-1972, 1999, p. 7880 . 
BRABOURNE, Lord. "Letters from Jane Austen to Fanny Knight". In: Letters of Jane Austen. Brabourne Edition, $1884 . \quad$ Available at: http://www.pemberley.com/janeinfo/brablt15.html

BROOKER, Peter. "Postmodern Adaptation: pastiche, intertextuality and refunctioning”. In: CARTMELL, Debora; WHELEHAN, Imelda. The Cambridge Companion to Literature on screen. Cambridge, 2007, p. 107-120.

CARTMELL, Deborah; WHELEHAN, Imelda. The Cambridge Companion to Literature on screen. Crambridge, 2007.

ELIOT, T. S. Tradition and the Individual Talent. In: The Sacred Wood: Essays on Poetry and Criticism. 1922.

FERGUS, Jen. "Biography". In: TODD, Janet. Jane Austen in context. United Kingdom: Cambridge University Press, 2005, p. 3-11.

HARMAN, Claire. Jane's fame: how Jane Austen conquered the world. Great Britain: Canongate Books, 2009.

HUTCHEON, Linda, with O'FLYNN, Siobhan. A theory of adaptation. $2^{\text {nd }}$ ed. New York: Routledge, 2013.

LE FAYE, Deydre. Jane Austen: The world of her novels. London: Frances Lincoln, 2002.

MCFARLANE, Brian. "Reading Film and Literature". In: CARTMELL, Debora. The Cambridge Companion to Literature on Screen. Cambridge, 2007, p. 15-28.

MISS AUSTEN REGRETS. Directed by: Jeremy Lovering. Script by: Gwyneth Hughes. Cast: Olivia Williams, Samuel Roukin, Greta Scacchi, Hugh Bonneville. USA-UK, PBS, 2008. (90 min)

PERSUASION. Directed by Adrian Shergold. Screenplay by: Simon Burke. Cast: Sally Hawkins, Alice Krige, Rupert Penry-Jones, Anthony Head. UK, ITV, 2007 (120 min)

PLAZA, Julio. Tradução Intersemiótica. São Paulo: Perspectiva, 2003.

RAMBRAG, Ana Iris. Meet Jane Austen: the author as a character in contemporary derivative works. UFRGS, 2013. (Master's Thesis)

STAM, Robert. "Introduction: theory and practice of adaptation". In: Stam, R. and Raengo, A. A Companion to Literature and Film. Oxford: Blackwell, 2005, p. 1-52. 
SUTHERLAND, Katherine. 'Jane Austen'a Life and Letters. In: JOHNSON, Claudia. TUITE, Clara. A Companion to Jane Austen. Oxford: Wiley \& Blackwell, 2009, p. 13-30.

TROOST, Linda. "The Nineteenth-century Novel on Film: Jane Austen". In: CARTMELL, Debora. The Cambridge Companion to Literature on screen. Cambridge, 2007, p. 75-89. 